\section{Polymorphism at the D20S13 (p $\phi 64)$ locus}

\author{
P.B.Chappell, A.J.Pakstis, C.H.Carr ${ }^{1}$ and \\ R.W.Deed ${ }^{1,+}$ \\ Department of Human Genetics, Yale University \\ School of Medicine, New Haven, CT 06510, \\ USA and ${ }^{1}$ Paterson Institute for Cancer \\ Research, Cell Biology Laboratory, Christie \\ Hospital and Holt Radium Institute, Manchester \\ M20 9BX, UK
}

Source and Description: The probe was isolated from a Charon 21A bacteriophage human chromosome 20 specific library (1), and subcloned as a HindIII fragment into pUC19.

Polymorphism: PvuII detects a two allele polymorphism with allelic bands at either $4.4 \mathrm{~kb}$ or $3.4 \mathrm{~kb}$. MspI detects a three allele polymorphism with allelic bands at $9.4 \mathrm{~kb}, 8.2 \mathrm{~kb}$ or $6.3 \mathrm{~kb}$. No constant bands appear with PvuII but a faint constant band occurs at $4.2 \mathrm{~kb}$ with MspI.

Frequency: Gene frequencies are based on a sample of 278 chromosomes from 139 unrelated persons of mixed Caucasian ancestry.

\begin{tabular}{|c|c|c|c|c|}
\hline \multirow{3}{*}{ PvuII } & Allele & Frequency & Allele & Frequency \\
\hline & Al $4.4 \mathrm{~kb}$ & 0.78 & MspI B1 $9.4 \mathrm{~kb}$ & 0.78 \\
\hline & $\mathrm{A} 23.4 \mathrm{~kb}$ & 0.22 & $\begin{array}{l}\text { B2 } \\
\text { B3 } 6.3 \mathrm{~kb}\end{array}$ & $\begin{array}{l}8.2 \mathrm{~kb} \\
\text { rare }\end{array}$ \\
\hline
\end{tabular}

Except when a rare allele occurred with MspI in 5 related individuals in one family, PvuII and MspI show complete linkage disequilibrium $(\mathrm{A} 1 \mathrm{~B} 1=.78 ; \mathrm{A} 2 \mathrm{~B} 2=.22)$ suggesting a single difference in the DNA may be causing both RFLPs, for example, a small insertion/deletion.

Not Polymorphic For: RsaI, DraI, StuI, EcoRI, SacI, BamHI, BglI, HindIII, PstI on a panel of 11 unrelated persons.

Chromosomal Localization: Using a somatic cell hybrid panel (2), the probe was localized to chromosome 20p. Preliminary linkage analyses (3) give lod scores above 4 with D20S5 and D20S6, confirming the mapping to 20p.

Mendelian Inheritance: Mendelian inheritance has been demonstrated in 7 large families.

Probe Availability: Freely available from R.W.Deed or K.K.Kidd.

Other Comments: $\mathrm{p} \phi 64$ has a repeat element and thus requires hybridization with an excess of unlabelled denatured DNA.

Acknowledgements: Supported in part by USPHS grant MH39239 and a Tourette Syndrome Association grant to K.K.Kidd.

References: 1) van Dilla,M.A. et al. (1986) Biotechnology 4, 537-552. 2) Sacchi,N. et al. (1986) Science 231, 379-382. 3) Chappell,P.B. et al. (1989) Cytogenetics and Cell Genetics 51, 975-976.

+Present address: Molecular Oncology Laboratory, Imperial Cancer Research Fund Laboratories, St. Bartholomews Hospital, London EC1A 7BE, UK

\title{
Two EcoRI RFLPs at the GLUT2 locus
}

P.Patel ${ }^{2}$, G.I.Bell ${ }^{1}$, R.C.Turner and

J.S.Wainscoat ${ }^{2}$

Diabetes Research Laboratories, Nuffield

Department of Clinical Medicine, Radcliffe

Infirmary, Oxford, UK, ${ }^{1}$ Howard Hughes

Medical Institute, University of Chicago, 920 East

58th Street, Chicago, IL 60637, USA and

${ }^{2}$ Department of Haematology, John Radcliffe

Hospital, Headington, Oxford OX3 9DU, UK

Source and Description: pGEM 4Z/HTL 3 is a human glucose transport-like protein (GLUT2) cDNA clone containing $2.4 \mathrm{~Kb}$ SalI insert.

Polymorphism: Restriction endonuclease EcoRI identifies two polymorphisms. The first is a two allele polymorphism (E1), with bands at $5.6 \mathrm{~Kb}$ and $3.4 \mathrm{~Kb}$. The second is a two allele polymorphism (E2) with bands at $1.9 \mathrm{~Kb}$ and $1.8 \mathrm{~Kb}$. The invariant bands are at $6.8 \mathrm{~Kb}, 4.5 \mathrm{~Kb}$ and $3.8 \mathrm{~Kb}$.

Frequencies: Studied in 22 unrelated European Caucasian individuals:

E1 $-5.6 \mathrm{~Kb}$ allele: 0.84 $3.4 \mathrm{~Kb}$ allele: 0.16

E2 - 1.9 Kb allele: 0.07 $1.8 \mathrm{~Kb}$ allele: 0.93

Chromosomal Localization: Assigned to chromosome $3 q 26.1-3 q 26.3$ using a panel of mouse-human somatic cell hybrids and by in situ hybridization to metaphase chromosomes (1).

Mendelian Inheritance: Co-dominant segregation of the two polymorphisms (E1 and E2) observed in one Caucasian family (19 individuals).

Probe Availability: Contact G.I.Bell.

Acknowledgement: This work was supported by a grant from the Medical Research Council (UK).

Reference: 1) Fukumoto,H. et al. (1988) Proc. Natl. Acad. Sci. USA 85, 5434-5438.

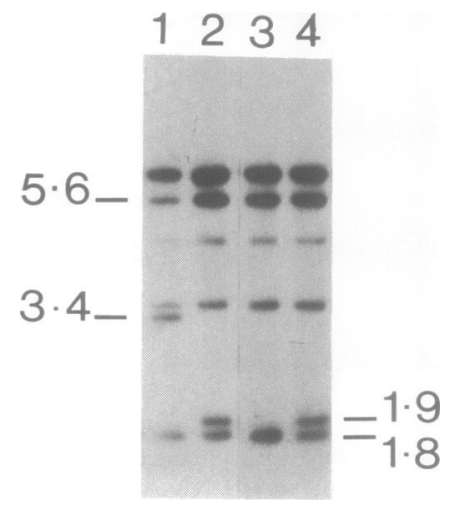

